\title{
High Sensitivity C-Reactive Protein sebagai Parameter Diagnostik dan Prediktor Luaran Sepsis pada Anak yang Menderita Systemic Inflammatory Response Syndrome
}

\author{
Sofni Sarmen, ${ }^{*}$ Mayetti, * Hafni Bachtiar ** \\ *Bagian Ilmu Kesehatan Anak, ${ }^{* *}$ Bagian Ilmu Kesehatan Masyarakat Fakultas Kedokteran Universitas \\ Andalas/RS. M Djamil, Padang
}

\begin{abstract}
Latar belakang. Sepsis merupakan salah satu penyebab morbiditas dan mortalitas pada anak. Diagnosis sepsis ditegakkan berdasarkan gejala Systemic Inflammatory Response Syndrome (SIRS) dan penemuan bakteri pada kultur darah. Kultur bakteri darah memiliki sensitifitas yang rendah dan membutuhkan waktu yang lama sehingga sering menyebabkan terjadinya overdiagnosis dan overtreatment. C-reactive protein adalah reaktan fase akut yang kadarnya meningkat pada keadaan infeksi. High sensitivity $C$-reactive protein (hsCRP) adalah metode yang lebih sensitif untuk mengukur kadar CRP dalam jumlah kecil.

Tujuan. Mengetahui peran hs-CRP sebagai parameter diagnostik dan prediktor luaran sepsis pada anak yang menderita SIRS.

Metode. Penelitian uji diagnostik dengan desain potong lintang terhadap 85 anak dengan gejala SIRS berusia 1 bulan sampai dengan 15 tahun dan dirawat di bangsal anak RS.Dr.M.Djamil Padang sejak Juni sampai November 2012. Pemeriksaan hs-CRP dilakukan dengan metode enzyme-linked immunosorbent assay (ELISA). Data dianalisis dengan SPSS serta dilakukan uji diagnostik. Baku emas sepsis adalah biakan darah.

Hasil. Cut off point hs-CRP untuk menentukan sepsis adalah $15,55 \mathrm{ng} / \mathrm{ml}$, (sensitivitas $90,9 \%$ dan spesivisitas $53,8 \%$ ). Kadar rata-rata hs-CRP meningkat sesuai dengan beratnya penyakit.

Kesimpulan. High sensitivity C-reactive protein dapat dijadikan sebagai parameter diagnostik sepsis pada pasien SIRS dengan cut off point 15,55 $\mathrm{ng} / \mathrm{ml}$, serta dapat dipakai sebagai prediktor luaran sepsis.

Sari Pediatri 2014;16(4):278-83.
\end{abstract}

Kata kunci: high sensitivity C-reactive protein (hs-CRP), systemic inflammatory response syndrome (SIRS), sepsis, anak.

\footnotetext{
Alamat korespondensi:

Dr. Sofni Sarmen, Sp.A. Bagian Ilmu Kesehatan Anak Rumah Sakit Dr. M. Djamil Padang. Jl Perintis Kemerdekaan. Padang. E-mail: sofnisarmen@yahoo.co.id
}

epsis merupakan masalah kesehatan utama pada anak karena menyebabkan morbiditas dan mortalitas yang tinggi. Apabila organisme patogen seperti bakteri masuk ke dalam 
tubuh, eliminasi tidak efektif karena terjadi kegagalan mekanisme pertahanan tubuh secara umum sehingga akan menyebabkan systemic inflammatory response syndrome. ${ }^{1-3}$ Sepsis dapat berkembang menjadi sepsis berat, syok septik, multiple organ dysfunction syndrome (MODS), dan kematian. ${ }^{4,5}$ Diagnosis pasti sepsis ditegakkan dengan penemuan bakteri pada kultur darah. Gejala klinis sepsis sering tidak spesifik, sedangkan hasil pemeriksaan kultur yang merupakan baku emas dalam penegakan diagnosis sepsis sensitifisitasnya masih rendah (30\%-50\%) dan membutuhkan waktu 48-72 jam. Hal ini menyebabkan terjadi overdiagnosis dan overtreatment antibiotik. Bahkan, keterlambatan tata laksana akan meningkatkan lama rawat di rumah sakit, biaya, dan risiko infeksi nosokomial. ${ }^{5}$

Systemic inflammatory response syndrome merupakan kaskade inflamasi yang diawali oleh respon host terhadap faktor infeksi dan bukan infeksi. ${ }^{4,5}$ Pada infeksi bakteri, terjadi pelepasan sitokin inflamasi, seperti tumor necrosis factor (TNF)- $\alpha$, Interleukin (IL)-1 $\beta$, IL-8, dan IL-6, ${ }^{6}$ yang akan mencetuskan produksi $C$ reactive protein oleh hepatosit yang dapat ditemukan dalam darah. ${ }^{7-9} C$-reactive protein berperan penting pada respon imun innate dan telah dikenal merupakan salah satu petanda inflamasi. Individu tanpa inflamasi biasanya memiliki kadar CRP $<1 \mathrm{mg} / \mathrm{L}$, kadar CRP bisa meningkat sampai 100 kali lipat nilai normal pada kasus inflamasi akut, seperti infeksi, trauma, keganasan dan pembedahan. ${ }^{4,9,10}$ Hal ini dapat dipakai sebagai pertanda adanya infeksi pada anak yang menderita SIRS tanpa riwayat trauma dan pembedahan.

High sensitivity $C$-reactive protein merupakan metode yang sangat sensitif untuk mengukur CRP sehingga dapat mendeteksi CRP lebih awal pada SIRS yang disebabkan oleh infeksi bakteri (sepsis). ${ }^{10}$ Penelitian ini bertujuan untuk mengetahui perananan hs-CRP sebagai parameter diagnostik dan prediktor luaran sepsis pada anak yang menderita SIRS.

\section{Metode}

Penelitian uji diagnostik dengan desain potong lintang, pengamatan klinis sampel penelitian saat masuk sampai pulang dari rumah sakit. Penelitian dilakukan pada bulan Juni-November 2012 di bangsal rawat inap bagian anak RS Dr. M. Djamil Padang.

Subjek penelitian adalah anak usia 1 bulan-15 tahun yang menderita SIRS. Diagnosis ditegakkan apabila terdapat dua atau lebih kriteria (suhu tubuh inti $>38,5^{\circ} \mathrm{C}$ atau $<36^{\circ} \mathrm{C}$, takikardi/ bradikardi, takipnue, leukopeni/ leukositosis). Salah satu kriteria tersebut adalah harus terdapat perubahan suhu tubuh atau hitung leukosit yang abnormal. ${ }^{2}$

Subjek tidak diikutsertakan dalam penelitian apabila menderita penyakit keganasan (limfoma, karsinoma, sarkoma, leukemia), trauma (pembedahan, luka bakar, fraktur), nekrosis (tumor embolization, pankreatitis akut), penyakit inflamasi (Juvenile chronic arthritis, ankylosing spondylitis, psoriatic arthritis, systemic vasculitis, polymyalgia rheumatic, Reiter disease, Crohn disease, familial mediterranean fever, infark myocardial), penyakit lain yang dapat memengaruhi kadar CRP (systemic lupus erythematosus, skleroderma, dermatomiositis, ulcerative colitis, Graft-versus-host disease), mendapatkan vaksinasi 5 hari sebelumnya, telah mendapatkan antibiotik sebelumnya, dicurigai terinfeksi virus, serta anak yang pulang dalam rawatan atas permintaan sendiri. Pemilihan subjek dilakukan dengan metode random blok. Jumlah subjek 85 pasien, dihitung berdasarkan rumus sampel untuk estimasi proporsi suatu populasi.

Penelitian diawali dengan mendeteksi seluruh pasien SIRS yang sesuai dengan kriteria inklusi dan ekslusi. Dilakukan pengambilan sampel darah saat masuk RS (hari 1), $3 \mathrm{ml}$ untuk pemeriksaan hs-CRP dengan metode ELISA (Enzyme Linked Immunosorben Assay) dengan alat ukur The Quantikinine human hs-CRP immuoassay dengan sensitivitas $0,01 \mathrm{ng} / \mathrm{ml}$ dan $2 \mathrm{ml}$ untuk kultur bakteri darah dengan media Bactec plus.

Laboratorium yang digunakan adalah laboratorium biomedik Fakultas Kedokteran Universitas Andalas Padang. Kemudian dilakukan observasi derajat klinis sampai pasien pulang dari RS. Persetujuan etik diperoleh dari komite etik RS Dr M Djamil Padang.

Data diolah dengan menggunakan program SPSS 15. Sensitivitas, spesifisitas, nilai duga positif (NDP), nilai duga negatif (NDN) didapatkan dengan membandingkan hasil hs-CRP dengan kultur bakteri darah sebagai baku emas sepsis. Seluruh hasil hsCRP dimasukkan ke dalam kurva receiver operating characteristic (ROC) untuk mencari nilai titik potong nilai hs-CRP yang paling baik. Data disajikan dalam bentuk tekstular dan tabular. 


\section{Hasil}

Terdapat 85 orang anak yang memenuhi kriteria penelitian. Jumlah anak perempuan hampir sama dengan anak laki-laki, usia terbanyak $>1-5$ tahun $(30,6 \%)$ (Tabel 1).
Pada pasien yang terbukti sepsis didapatkan kadar hs-CRP lebih tinggi secara signifikan dibandingkan kultur bakteri darah $(\mathrm{p}=0,000)$ (Tabel 3). Sensitivitas hs-CRP untuk sepsis adalah 97\%, spesifisitas 38,5\%, nilai duga positif (NDP) $50 \%$ dan nilai duga negatif (NDN) 95,2\% (Tabel 4).

Tabel 1. Kriteria SIRS menurut golongan umur ${ }^{2}$

\begin{tabular}{|c|c|c|c|c|}
\hline \multirow{2}{*}{ Usia } & \multicolumn{2}{|c|}{ Frekuensi laju nadi (x/menit) } & \multirow{2}{*}{$\begin{array}{l}\text { Frekuensi nafas ( } \mathrm{x} / \\
\text { menit) }\end{array}$} & \multirow{2}{*}{$\begin{array}{l}\text { Jumlah leukosit }\left(\mathrm{x} 10^{3} /\right. \\
\left.\mathrm{mm}^{3}\right)\end{array}$} \\
\hline & Takikardi & Bradikardi & & \\
\hline $0-7$ hari & $>180$ & $<100$ & $>50$ & $>34$ \\
\hline 7-30 hari & $>180$ & $<100$ & $>40$ & $>19,5$ atau $<5$ \\
\hline $1-12$ bulan & $>180$ & $<90$ & $>34$ & $>17,5$ atau $<5$ \\
\hline $1-5$ tahun & $>140$ & NA & $>22$ & $>15,5$ atau $<6$ \\
\hline 6-12 tahun & $>130$ & NA & $>18$ & $>13,5$ atau $<4,5$ \\
\hline 13-18 tahun & $>110$ & NA & $>14$ & $>11$ atau $<4,5$ \\
\hline
\end{tabular}

Suhu tubuh $>38,5^{\circ} \mathrm{C}$ atau $<36^{\circ} \mathrm{C}$

$\mathrm{NA}=$ not applicable

Tabel 2. Karakteristik pasien

\begin{tabular}{lcc}
\hline Karakteristik & $\mathrm{n}$ & $\%$ \\
\hline Jenis kelamin & & \\
$\quad$ Laki-laki & 41 & 48,2 \\
Perempuan & 44 & 51,8 \\
Kelompok usia & & \\
1 bulan -1 tahun & 25 & 29,4 \\
$>1-1$ tahun & 26 & 30,6 \\
$>5-10$ tahun & 18 & 21,2 \\
$>10-15$ tahun & 16 & 18,8 \\
\hline
\end{tabular}

Usia, rerata (SD) bulan: 53,5 $(50,7)$
Cut off point hs-CRP untuk menentukan sepsis $15,55 \mathrm{ng} / \mathrm{mL}$, dengan sensitivitas $90,9 \%$ dan spesifisitas $53,8 \%$ (Tabel 5). Terlihat titik yang terjauh dari garis diagonal menunjukkan sensitivitas dan spesifisitas hs-CRP yang paling tinggi untuk menentukan sepsis (Gambar 1). Terdapat perbedaan yang bermakna secara statistik kadar hs-CRP rerata anak yang mengalami unproven sepsis, sepsis, sepsis berat, syok sepsis dan meninggal. Kadar hs-CRP rata-rata tertinggi ditemukan pada sepsis berat, yaitu 19,00 $(4,59) \mathrm{ng} /$ $\mathrm{mL}$ (Tabel 6).

Tabel 3. Kadar hs-CRP rata-rata berdasarkan kultur bakteri darah

\begin{tabular}{lccc}
\hline Kultur bakteri darah & $\mathrm{n}$ & Hs-CRP, (SD) ng/mL & $\mathrm{p}$ \\
\hline Positif & 33 & $19,47(3,019)$ & 0,000 \\
Negatif & 52 & $13,30(7,877)$ & \\
\hline
\end{tabular}

Tabel 4. Uji diagnostik hs-CRP berdasarkan baku emas kultur bakteri darah

\begin{tabular}{lccc}
\hline \multirow{2}{*}{ Hs-CRP } & \multicolumn{2}{c}{ Kultur bakteri darah } & \multirow{2}{*}{ Total } \\
\cline { 2 - 3 } & Positif & Negatif & 64 \\
Positif & 32 & 32 & 21 \\
Negatif & 1 & 20 & 85 \\
Total & 33 & 52 & \\
\hline
\end{tabular}


Tabel 5. Cut off point kadar hs-CRP

\begin{tabular}{lccc}
\hline Nilai asumsi hs-CRP ng/mL & Sensitivitas $(\%)$ & Spesifitas $(\%)$ & Kappa \\
\hline 6,85 & 100 & 26,9 & 0,222 \\
7,87 & 100 & 28,8 & 0,239 \\
8,07 & 100 & 30,8 & 0,257 \\
9,15 & 97 & 34,6 & 0,267 \\
11,84 & 97 & 44,2 & 0,357 \\
12,13 & 97 & 44,2 & 0,357 \\
14,78 & 93,9 & 50 & 0,388 \\
15,55 & 90,9 & 53,8 & 0,401 \\
16,83 & 84,8 & 53,8 & 0,350 \\
17,39 & 87,9 & 55,8 & 0,395 \\
18,79 & 84,8 & 57,7 & 0,389 \\
19,65 & 81,8 & 59,6 & 0,383 \\
20,97 & 60,6 & 71,2 & 0,314 \\
21,06 & 51,1 & 73,1 & 0,249 \\
\hline
\end{tabular}

Tabel 6. Kadar hs-CRP rata-rata berdasarkan luaran derajat klinis

\begin{tabular}{lccc}
\hline Luaran derajat klinis & $\mathrm{n}$ & Hs-CRP, Rerata (SD) $\mathrm{ng} / \mathrm{mL}$ & $\mathrm{p}$ \\
\hline Unproven sepsis & 23 & $10,28(8,26)$ & 0,000 \\
Sepsis & 24 & $16,87(6,00)$ & \\
Sepsis berat & 12 & $19,00(4,59)$ & \\
Syok septik & 3 & $18,55(4,79)$ & \\
Meninggal & 23 & $18,18(5,56)$ & \\
\hline
\end{tabular}

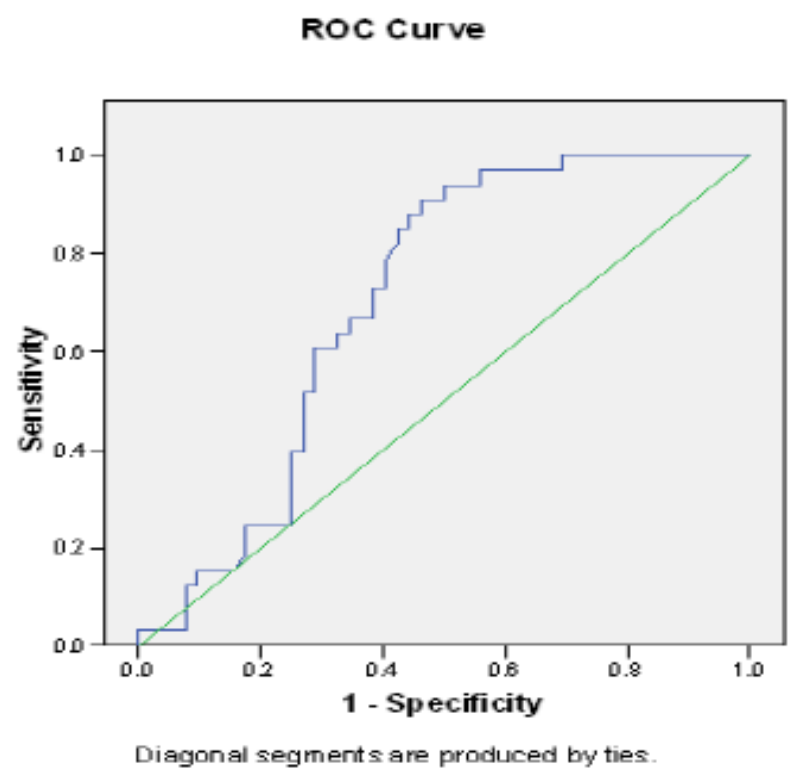

Gambar 1. Kurva ROC hs-CRP

\section{Pembahasan}

Jumlah anak yang mengalami sepsis berdasarkan kadar hs-CRP lebih banyak dibandingkan berdasarkan kultur bakteri darah. Hal tersebut sama dengan hasil penelitian Stolz $\mathrm{dkk}^{11}$ tentang sepsis yang disebabkan oleh bakteri. Jumlah anak yang mengalami sepsis berdasarkan kadar hs-CRP lebih banyak dibandingkan kultur darah. Spesifisitas hs-CRP yang rendah mungkin disebabkan karena kultur yang dilakukan hanya kultur bakteri darah saja sehingga tidak dapat menghindarkan kemungkinan virus dan jamur sebagai penyebab sepsis, walaupun pada penelitian ini menggunakan metode Bactec yang memiliki sensitifitas hampir $80 \%$.

Bactec Peds plus merupakan media biakan darah yang diperkaya oleh Soybean-Casein Digest broth dengan $\mathrm{CO} 2$ dan merupakan media biakan darah aerobik. Prinsip pemeriksaan Bactec ini adalah meningkatnya fluoresensi sensor vial karena kadar $\mathrm{CO} 2$ yang tinggi yang dihasilkan oleh kuman aerob. Bactec Peds plus mengandung resin yang berfungsi menetralisir antimi- 
kroba dalam sampel darah, tetapi resin ini tidak adekuat menetralisir antimikroba Imipenem-Cilastatin. ${ }^{12}$

Cut off point hs-CRP untuk menetapkan sepsis adalah $15,55 \mathrm{ng} / \mathrm{ml}$. Hasil tersebut lebih rendah dibandingkan dengan penelitian Grenc $\mathrm{dkk}^{13}$ yang mendapatkan cut off point CRP $17 \mathrm{mg} / \mathrm{L}$ pada anak dan bayi yang mengalami sakit berat. Pada penelitian lainnya, Galetto dkk ${ }^{14}$ mendapatkan cut off point 40 $\mathrm{mg} / \mathrm{dL}$ pada anak yang mengalami infeksi berat dengan gejala demam.

Sensitifitas hs-CRP penelitian kami lebih tinggi dibandingkan dengan penelitian Grenc yang mendapatkan sensitivitas hs-CRP $83 \%$, spesifisitas $75 \%$, NDP $31 \%$, dan NDN 97\% ${ }^{13}$ dan penelitian Galetto yang mendapatkan sensitivitas hs-CRP 79\%, spesifisitas 79\%, NDP 61\%, dan NDN 90\%. ${ }^{14}$

Sensitivitas dan spesifisitas hs-CRP yang bervariasi dapat disebabkan oleh perbedaan cut off point hs-CRP rata-rata yang diambil untuk menetapkan sepsis. Untuk membedakan infeksi bakteri, virus, dan keadaan inflamasi non infeksi, CRP saja kurang spesifik sehingga sering dikombinasi dengan biomarker lainnya sebagai penunjang untuk menegakkan diagnosis sepsis. ${ }^{10}$ Kombinasi Interleukin-6 dengan CRP untuk diagnosis dini infeksi pada anak, memiliki sensitivitas $94 \%$ dan spesifisitas $94 \% .5,15$

Kadar hs-CRP rata-rata tertinggi didapatkan pada sepsis berat dengan perbedaan pada kelompok unprovent sepsis, sepsis, sepsis berat, dan meninggal. Hal tersebut hampir sama dengan penelitian Pullian $\mathrm{dkk}^{16}$ yang melaporkan bahwa kadar CRP pada pasien yang mengalami infeksi bakteri berat adalah $9,7 \mathrm{mg} / \mathrm{L}$ dan ringan adalah $1 \mathrm{mg} / \mathrm{L}$ dengan perbedaan yang bermakna. Kadar CRP akan meningkat dalam 6 jam di dalam serum apabila terjadi proses inflamasi akut. Kadar CRP dalam plasma dapat meningkat dua kali lipat, sekurangnya setiap 8 jam dan mencapai puncaknya setelah kira-kira 50 jam. Setelah pengobatan yang efektif dan rangsangan inflamasi hilang maka kadar CRP akan turun secepatnya. ${ }^{4,17}$

\section{Kesimpulan}

High sensitivity C-reactive protein dapat dijadikan sebagai parameter diagnostik sepsis pada pasien SIRS dengan cut off point $15,55 \mathrm{ng} / \mathrm{mL}$, dengan sensitivitas dan spesifisitas yang tinggi. Kadar rata-rata hs-CRP saat masuk RS pada anak yang menderita SIRS sesuai dengan beratnya derajat klinis akhir rawatan, sehingga dapat dipakai sebagai prediktor luaran sepsis.

\section{Ucapan terimakasih}

Terimakasih disampaikan kepada Ketua Program Studi Ilmu Kesehatan Anak FK UNAND, Ketua Bagian Ilmu Kesehatan Anak FK UNAND RS Dr M Djamil Padang, seluruh staf Ilmu Kesehatan Anak FK UNAND, dan teman sejawat yang telah berpartisipasi dalam pelaksanaan penelitian kami.

\section{Daftar pustaka}

1. Pavare J, Grope I, Gardovska D. Prevalence of systemic inflammatory response syndrome (SIRS) in hospitalized children: a point prevalence study. BMC Pediatr 2009;25:1-6.

2. Goldstein B, Giroir, Randolph A, The Members of the International consensus conference on pediatric sepsis. International pediatric sepsis consensus conference: definitions for sepsis and organ dysfunction in pediatrics. Pediatr Crit Care Med 2005;6(Suppl 3): 2-8.

3. Short MA. Linking the sepsis triad of inflammation, coagulation, and suppressed fibrinolysis to infants. Adv Neonatal Care 2004;5:258-73.

4. Enrione MA, Powell KR. Sepsis, septic shock, and systemic inflammatory response syndrome. Dalam: Kliegman RM, Behrman RE, Jenson HB, Stanton BF, penyunting. Nelson textbook of pediatrics. Edisi ke-18. Philadelphia:Saunders; 2007.h.1094-9.

5. Thomas NJ, Tamburro RF, Hall MW, Rajasekaran S, Venglarcik JS. Bacterial sepsis and mechanisms of microbial pathogenesis. Dalam: Nichols DG, penyunting. Roger's Textbook of Pediatric Intensive Care. Edisi ke-4. Baltimore: Lippincott Williams \& Wilkins; 2008. h.477-88.

6. Ventetuolo CE, Levy MM. Biomarkers: diagnosis and risk assessment in sepsis. Clin chest med J 2008:h.591603.

7. Pavare J, Grope I, Eihvalde L, Gardovska D. Diagnostic markers for identifying sepsis in patients with systemic inflammatory response syndrome (SIRS): A Prospective Study. The Open Pediatr Med J 2009;3:1-7.

8. Castellheim A, Brekke O-L, Espevik $\$$ T, Harboe M, Mollnes T. Innate immune responses to danger signals in systemic inflammatory response syndrome and sepsis. J Imuno 2009;69:479-91.

9. Standage SW, Wong HR. Biomarkers for pediatric 
sepsis and septic shock. Expert Rev. Anti Infect. Ther 2011;9:71-9.

10. Human high sensitivity C-Reactive protein (hs-CRP) ELISA Kit. Diakses tanggal 4 Februari 2012. Didapat dari : http://www. Hs CRP.

11. Stolz D, Stulz A, Muller B, Gratwohl A, Tamm M. BAL neutrophils, serum procalcitonin, and C-Reactive Protein to predict bacterial infection in the immunocompromised host. Chest.2007;132:504-14.

12. Bactec Ped Plus Catalog. Diakses tanggal 08 Februari 2011 Didapat dari: www.bactec.com.

13. Grenc MG, Ihan A, Arnol MP, Kopitar AN, Stopar TG, Derganc M. Neutrophil and monocyte CD64 indexes, lipopolysaccharide-binding protein, procalcitonin and C-reactive protein in sepsis of critically ill neonates and children. Int Care Med J 2009;35:1950-58.
14. Galetto-Lacour A, Zamora SA, Gervaix A. Bedside procalcitonin and C-Reactive Protein tests in children with fever without localizing signs of infection seen in a referral center. AAP J 2003;112:1054-60.

15. Carcillo JA, Planquois JM, Goldstein B. Early markers of infection and sepsis in newborns and children. Adv Sepsis 2006;5:118-25.

16. Pulliam PN, Attia MW, Cronan KM. M. Cronan undetectable serious bacterial infection C-reactive protein in febrile children 1 to 36 months of age with clinically undetectable serious bacterial infection. Pediatr J 2001;108:1275.

17. Puopolo KM. Bacterial and fungal infections. Dalam: Cloherty JP, Stark AR, penyunting. Manual of neonatal care. Edisi ke-5. Boston: Lippincott Williams \& Wilkins; 2004.h.287-312. 